\title{
地盤の変形を考慮したべた基礎建物の鉛直荷重時実用解法 A PRACTICAL METHOD FOR STRESS ANALYSIS OF STRUCTURES WITH RAFT FOUNDATION CONSIDERING DEFORMATION OF THE GROUND UNDER VERTICAL LOADING
}

\author{
松尾雅夫*, 山肩邦男*** \\ Masao MATSUO and Kunio YAMAGATA
}

\begin{abstract}
It is known by the few examples that the structures with raft foundation possess the great efect of suppression to differential settlements. He suspect that this factors are the rigidity increase of superstructure by the raft's stiffness and the load dispersion by the large area of contact on the ground. I n this paper, we have proposed the practical analysis method for structures with raft foundation. This method is considered the interactive behavior of a soil-structure system and the non-1 inear property of superstructure and soil. On the case that the differential settlements of structures with raft foundation occured, we discuss the distribution of contact pressure and the stress of superstructure including the foundation beam and the mat slab by the use of numerical example.
\end{abstract}

Keywords :differential settlement, soil-structure interaction, stress analysis, raft foundation, non-linear, vertical laading 不同沈下，土と構造物の相互作用，応力解析，べた基礎，非線形，鉛直荷重時

1.はじめに

建築構造物の設計にあたっては、従来から上部構造と 下部構造とを切り離して、基礎は不同沈下しないという 前提で、構造計算が行われてきた。しかし現実には、上 部構造の支持点である基礎には多少とも沈下が発生する ので、不同沈下に基づく上部構造の応力が生じ、場合に よっては上部構造に大きな影響を与えることが分かって いる。このような基礎の不同视下現象を設計面に合理的 に取り入れるためには、地盤の変形と上部構造の変形を 適合させた検討が必要であって、このための実用的な解 析法の出現が望まれてきたところである。

筆者らは、このような観点に立って基礎と上部構造と の変形を適合させ、地盤の非線形変形特性および上部構 造の非線形変形特性を考慮した実用的な応力解析手法を 文献"に発表した。この解法は、上部構造の設計に多用 されている3 次元骨組解析プログラムに、地盤の変形を 連携させることによって構成したものであって、従来な おざりにされてきた不同沈下解析を、実用的な設計手法
として確立できたと考える。

また、同文献には不同沈下軽減対策として、基礎梁の 剛性を增大させた場合および浮基礎を採用した場合につ いての検討を行っており、いずれもその効果は大きいこ 之が確認できた。このことは、軟弱地盤上に建つ建物で あっても建物規模によっては十分な不同沈下対策を行う ことによって、支持杭に頼らず直接基礎として設計でき ることを示唆している。とくにべた基礎を有する建物は 接地面積が大きいことによる荷重分散効果があり、基礎 底盤による上部構造の剛性の高まりもあって、不同视下 対策としての効果が大きいものと推察される。事実、心゙ た基礎建物の実施例 ${ }^{2), 3)}$ において、かなりの沈下が発生 している場合でも顕著な沈下障害は見られず、独立基礎 形式に比べて不同沈下が軽减されているとみてよい。

ところで、現状のべた基礎建物の基礎設計では慣用的 に、下方からの接地圧がべた基礎底面全体にわたって平 面状に分布すると仮定し、底盤は 4 辺固定の長方形スラ ブ、基礎梁は柱脚において支持された連続梁とみなして
Yasui Architects \& Engineers, Inc., M. Eng.

Prof., Dept. of Architecture, Faculty of Engineering, Kansai Univ., Dr. Eng. 
応力算定を行っている。しかしながら、地盤の変形を考 慮する場合には、このような仮定での設計手法は決して 妥当であるとはいえず、変形条件を満たした合理的な設 計手法が必要であることは、論をまたない。

べた基礎建物の不同沈下解析については、Winkler地 盤上の梁として扱った B aker ${ }^{4)}$ の研究、地盤を連続体と し、即時沈下のみを扱った国田 ${ }^{5)}$ 、 Gagetas ${ }^{6)}$ 、松井・ 佐藤・稲井 ${ }^{7)}$ らの研究、即時沈下と圧密沈下を同時に考 慮した加藤・谷口・松岡の解析 ${ }^{8}$ 、 $、$ 上部層の即時沈下に 続いて下部層の压密沈下を時間過程を考慮して解析した 松浦・山本の研究 ${ }^{9}$ ) 等がある。しかし、いずれも適用範 囲が限られるか、理論への厳密性を求めるため、経時沈 下過程を逐次算定する必要があるなど、設計に取り入れ るには実用性がそしいものと判断される。

本論は、このような状況を踏まえて、文献" の解法を べた基礎建物に㹡張し、基礎底盤、基礎梁および上部架 構の変形之地盤の変形を適合させ、かつ上部構造および 地盤の非線形性を考慮したべた基礎建物の実用的な解析 手法を提案するものである。また、この解析法を適用し たべた基礎建物の計算例によって、不同沈下が生じた場 合の接地圧分布、基礎底盤、基硞梁の応力ならびに上部 架構の応力状態などについて、解析的な検討を行うもの である。なお、本論の一部はすでに文献 ${ }^{101,11)}$ において 中間発表を行っていることを、お断りしておく。

\section{2. 地盤の变形を考慮したべた基礎建物の応力算定法}

2.1 仮定条件および基本式の概要

本解法の仮定条件、基本式およびべた基礎底盤部分を 除く上部構造と地盤の非線形変形特性の扱いなどについ ては前報 ${ }^{1)}$ と同じであるが、推論の必要上これらの概要 を以下に示す。

\section{(1) 解析対象および仮定条件}

本解法の対象・仮定条件および各種の考慮事項は、以 下のごとくである。

1）原則として、直接基礎を対象とする。

2）地盤の変形は即時沈下および終局圧密沈下に限る。

3）即時沈下は、砂質土層・粘性土層ともに地盤の互層 状態に対して、S teinbrenner の多層近似解法を用いて 算定する。地盤の弾性係数はひずみ依存性を考慮して設 定する。

4）粘性土の圧密沈下は 1 次元圧密として扱い、地中応 力の伝達については地盤の互層状態にかかわらず、Boussinesqの理論解を基本とした解を用いる。変形係数は 体積圧縮係数 $\mathrm{m}$ 、を採用するが、m、は压密武験結果から 得られる $\mathrm{e} \sim \log \mathrm{P}$ 関係曲線上の有効応力に応じた值を 設定する。

5）上部構造は立体架構とする。また、部材の塑性化に
伴う剛性低下やクリープ変形を考慮する。

\section{(2) 基本式}

図一 1 の互層地盤上の立体架構（前報にならい、一応 独立基礎で表現してある）を考え、任意の $\mathrm{i}$ 基礎の沈下 量 $\mathrm{S}_{i}$ を(1)式で、全基礎の地盤変位の関係式を(2)式で 表す。

$$
\begin{aligned}
S_{i}=S_{i c}+S_{i e}=\sum_{r} \lambda_{i} \cdot\left(\sum_{j} \alpha_{i j} \cdot R_{j}\right) \\
\\
+\sum_{r}\left(\sum_{j} \gamma_{i j} \cdot R_{j}\right) \\
\left\{S_{F}\right\}=[F] \cdot\left\{R_{F}\right\} \rightarrow\left\{R_{F}\right\}=[F]^{-1} \cdot\left\{S_{F}\right\}
\end{aligned}
$$

ここに、 $\mathrm{S}_{\mathrm{i}} \mathrm{c}$ : $\mathrm{i}$ 基礎の圧密沈下量、 $\mathrm{S}_{\mathrm{i}} \mathrm{c}$ : $\mathrm{i}$ 基礎の 即時沈下量、, $\lambda_{i}=m_{v} m_{v i} \times H_{i}$ : 粘性土層定数 ( $i$ 基礎 直下の第 $\mathrm{r}$ 層の体積圧縮係数 $\times$ 層厚)、, $\alpha_{i j}$ ：応力伝達 係数 ( $\mathrm{j}$ 基礎の単位荷重によって $\mathrm{i}$ 基礎值下第 $\mathrm{r}$ 層に生 ずる応力増分）、 $R_{j}: j$ 基礎の鉊直荷重、 $\gamma_{i j}$ : 即時 沈下係数 ( $\mathrm{j}$ 基礎の単位荷重による $\mathrm{i}$ 基礎值下第 $\mathrm{r}$ 層の 即時沈下量)、 $\left\{\mathrm{S}_{\mathrm{F}}\right\}$ : 全基礎の沈下行列、 $[\mathrm{F}]$ : 地盤変 位の柔性マトリクス、 $\left\{\mathrm{R}_{\mathrm{F}}\right\}$ ：全基礎の鉛直荷重行列で ある。(2)式の $[\mathrm{F}]^{-1}$ を上部立体架構の全体剛性マトリ クスの基礎位置節点鉛直成分に加えることにより、地盤 変位を考虑した上部構造全体の関係式を得る。
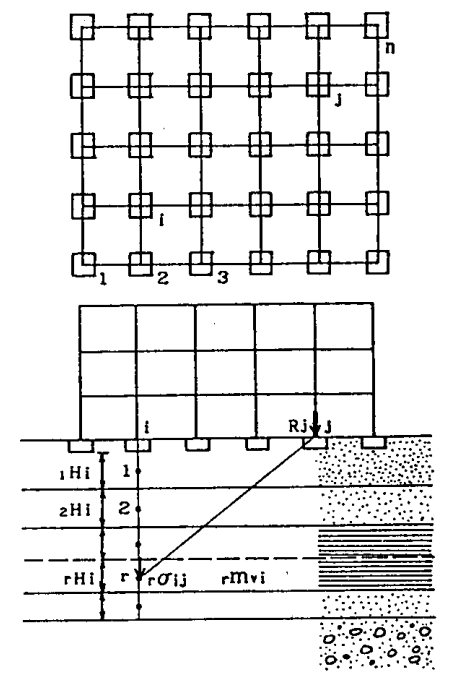

\section{図-1 地盤上の立体架構造}

\section{(3)地盤の非線形性の扱い}

粘性土の圧密沈下については、図一 2 の設計用 $\mathrm{e} \sim \log$ $\mathrm{P}$ 関係を用いて、任意の有効応力に対応する体積圧縮係 数m、を(3)式および(4)式により算定する。

$$
\begin{aligned}
\mathrm{m}_{\mathrm{v}} & =\frac{\mathrm{C}_{\mathrm{c}}\left(\text { または } \mathrm{C}_{\mathrm{s}}\right)}{\left(1+\mathrm{e}_{1}\right) \cdot \Delta \mathrm{P}} \cdot \log \left(\frac{\mathrm{P}_{1}+\Delta \mathrm{P}}{\mathrm{P}_{1}}\right) \\
\mathrm{e}_{1} & =\mathrm{e}_{\mathrm{a}}-\mathrm{C}_{\mathrm{s}} \times \log \left(\mathrm{P}_{1} / \mathrm{P}_{\mathrm{a}}\right) \quad\langle\mathrm{A} \sim \mathrm{C} \text { 間 }> \\
\mathrm{e}_{\mathrm{l}} & \left.=\mathrm{e}_{\mathrm{c}}-\mathrm{C}_{\mathrm{c}} \times \log \left(\mathrm{P}_{1} / \mathrm{P}_{\mathrm{c}}\right)<\mathrm{C} \sim \mathrm{B} \text { 間 }\right\rangle
\end{aligned}
$$

ここに、 $P_{1} 、 e_{1}$ ：任意点の有効応力および間隙比、 $\mathrm{P}_{a} 、 \mathrm{P}_{c} 、 \mathrm{e}_{a} 、 \mathrm{e}_{c}$ ：図-2に示す各点の有効応力およ び間隙比、 $\triangle \mathrm{P}: \mathrm{P}$ 、からの有効応力増分である。 


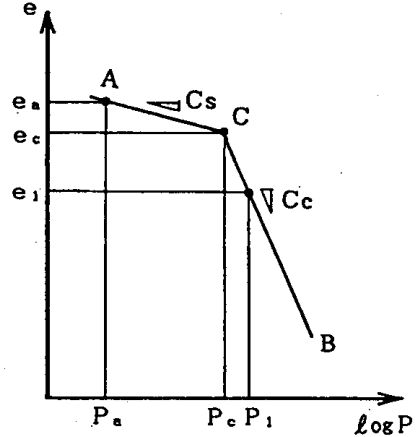

図-2 e $\log P$ 曲線のモデル化

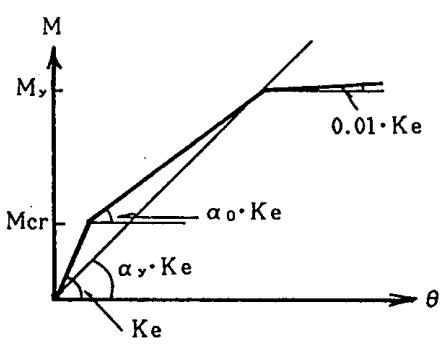

図-3 $\mathrm{M} \sim \theta$ 関係の近似

即時沈下については、ひずみ依存性を考慮した地盤の 弾性係数を文献 ${ }^{12)}$ より引用した次式により算定する。

$$
\mathrm{E}_{\mathrm{a}}=\left(\varepsilon / 10^{-4}\right)^{-0.55} \cdot \mathrm{E}_{\mathrm{ps}}
$$

こにに、 $\mathrm{E}_{\mathrm{a}}$ : 評価弾性係数 $\left(\mathrm{E}_{\mathrm{a}} \leqq \mathrm{E}_{\mathrm{ps}}\right) 、 \mathrm{E}_{\mathrm{ps}}: \mathrm{P}$ $\mathrm{S}$ 検層により求めた弾性係数、 $\varepsilon$ : 地層の鉛直方向のひ ずみである。

解析にあたっては、上部構造の荷重を区分し、その区 分荷重を順次載荷する増分解析法を採用する。 m、およ

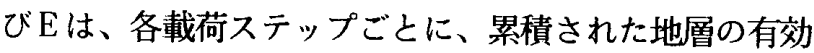
応力および鉛直ひずみから(3)〜 (5)式を用いて、逐次設 定しなおす。

\section{(4) 上部架構の非線形性の扱い}

コンクリート系の部材に限って、塑性化およびクリー プ変形の影響を以下の方法により考慮する。

部材の曲げモーメント $\mathrm{M} \sim$ 回転角 $\theta$ の関係を、図 -3 のトリリニア型の折線に近似して扱う。図中の記号は、 $\mathrm{M}_{\mathrm{c}}$ ：曲げひび割れモーメント、 $\mathrm{M}_{\mathrm{y}}$ ：曲げ降伏モーメン 卜、 $\mathrm{K}_{\mathrm{e}}$ : 初期曲げ剛性、 $\alpha_{0}$ : 第 2 勾配の剛性低下率、 $\alpha_{y}$ ：降伏時剛性低下率を示す。 $\mathrm{M}_{\mathrm{c}, \mathrm{r}} \bullet \mathrm{M}_{\mathrm{y}} \cdot \alpha_{\mathrm{y}}$ は文献 $^{13)}$ などから求め、 $\alpha_{0}$ は(6)式により求める。

$$
\begin{aligned}
& \alpha_{0}=\frac{\mathrm{M}_{\mathrm{y}}-\mathrm{M}_{\mathrm{cr}}}{\mathrm{M}_{\mathrm{y}} / \alpha_{\mathrm{y}}-\mathrm{M}_{\mathrm{c} r}} \\
& \mathrm{M} \leqq \mathrm{M}_{\mathrm{c}_{\mathrm{r}}} \text { の場合 } \mathrm{K}_{\mathrm{e} y_{\mathrm{i}}}=\mathrm{K}_{\mathrm{e}} \\
& \mathrm{M}_{\mathrm{c}_{\mathrm{r}}}<\mathrm{M} \leqq \mathrm{M}_{\mathrm{y}} \text { の場合 } \mathrm{K}_{\mathrm{eyi}}=\alpha_{0} \cdot \mathrm{K}_{\mathrm{e}} \\
& \mathrm{M}_{\mathrm{y}}<\mathrm{M} \text { の場合 } \mathrm{K}_{\mathrm{ey}}=0.01 \cdot \mathrm{K}_{\text {。 }}
\end{aligned}
$$

ここに、 $\mathrm{K}_{\mathrm{e} \text { y } \mathrm{i}}$ : i ステップでの塑性化による等価曲げ 㶡性である。

クリープによる変形は、クリープひずみがすべての応 力域で応力との間に線形関係が成り立つものとし、かつ
曲げを受ける断面に対して、（7)式および(8)式が適用で きるものと仮定する。

$$
\begin{aligned}
& \Delta \theta_{\mathrm{t}}=\frac{\mathrm{M}}{\mathrm{K}_{\mathrm{e}}} \phi_{\mathrm{mt}}, \mathrm{K}_{\mathrm{ect}}=\frac{1}{1+\phi_{\mathrm{mt}}} \cdot \mathrm{K}_{\mathrm{e}} \\
& \phi_{\mathrm{nt}}=(1-\beta) \phi_{\mathrm{t}}, \quad \beta=\frac{\mathrm{n} \cdot \mathrm{q}}{1-\mathrm{n} \cdot \mathrm{q}} \\
& \phi_{1}=\frac{0.75 \mathrm{t}}{1.5+0.25 \mathrm{t}} \quad(\mathrm{t} \text { は週単位 })
\end{aligned}
$$$$
\text { ここに、 } \Delta \theta_{\mathrm{t}} \text { : :曲げモーメントMによって生じる時 }
$$
間 $\mathrm{t}$ におけるクリープ回転角ひずみ、 $\mathrm{K}_{\mathrm{ec} \text { เ }}: \Delta \theta_{\mathrm{t}}$ を考 虑した等価曲げ剛性、 $\phi_{\mathrm{m} t}$ : 曲げに対する鉄筋コンクリ 一ト断面の等価クリープ係数、 $\mathrm{n}$ : 鉄筋とコンクリート のヤング係数比 $\left(\mathrm{E}_{\mathrm{s}} / \mathrm{E}_{\mathrm{c}}\right) 、 \mathrm{q}$ : 鉄筋とコンクリート の断面 2 次モーメント比 $\left(\mathrm{I}_{\mathrm{s}} / \mathrm{I}_{\mathrm{c}}\right) ; \phi_{\mathrm{t}}$ : コンクリー トのクリープ係数である。

なお、本解法では、終局沈下を対象としているため、 $\phi_{\mathrm{t}}=3(\mathrm{t}=\infty)$ を採用する。

塑性化とクリープ変形を同時に考虑する場合には、(9)

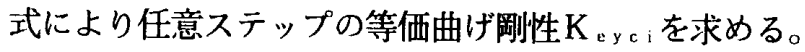

$$
\mathrm{K}_{\mathrm{ey} \mathrm{ci}}=\mathrm{K}_{\mathrm{ey} \mathrm{i}} \cdot \frac{1}{1+\phi_{\mathrm{mt}}}
$$

\section{2 ベた基礎底盤のモデル化}

ベた基礎建物では、建物荷重は基礎梁および底盤をと おして地盤に伝達されるため、底盤と地盤との間の相互 作用を考慮する必要がある。上部構造にべた基礎の底盤 を取り入れるための手法としては、一般に格子梁に分割 する方法、板曲げ要素として扱う方法などが考えられる （図一 4 参照）。いずれの方法も、底盤の応力および変 形は結合節点（斜線部の負担面積を代表）においてのみ 要素間で一致しており、かつ地盤変位と各節点の変位が 適合していると考えるため、底盤の分割状態によっては 解析精度に問題が生ずる可能性がある。したがって、底 盤を本解法に導入するにあたり、まずこれらのモデル化 の妥当性の検討を行う。

\section{（1）分割形状の検討}

図－5に示す 4 辺固定の床版に等分布荷重が作用する 場合について、床版を格子梁(ねじれ剛性の有無を含む) と長方形板曲げ要素にモデル化し、その分割数を変化さ せた計算を行うことによって、厳密解 ${ }^{(4)}$ と比較するこ ととする。図-6の長方形板曲げ要素の㴊性マトリクス は有限要素法による板曲げ解析として従来から扱われて いるものであり、(10)式で示される14)。

$$
\begin{aligned}
& \left\{\mathrm{P}_{i}, \mathrm{~T}_{\mathrm{xi}_{i}}, \mathrm{~T}_{y_{i}}\right\}^{\mathrm{T}}{ }_{i=1,2}, 3,4 \\
& \quad=[\mathrm{K}] \cdot\left\{\mathrm{W}_{i}, \theta_{x_{i}}, \theta_{y_{i}}\right\}^{\mathrm{T}} i=1,2,3,4
\end{aligned}
$$

ここに、 $[\mathrm{K}]$ : 長方形板の剛性マトリクス、 $\mathrm{P}_{\mathrm{j}}: \mathrm{Z}$ 方向面外力、 $\mathrm{T}_{\mathrm{x} i} \cdot \mathrm{T}_{\mathrm{y} i}: \mathrm{x}$ 軸廻り $\cdot \mathrm{y}$ 軸廻りの回転力、 $\mathrm{W}_{\mathrm{i}}: \mathrm{z}$ 方向変位、 $\theta_{\mathrm{x}_{\mathrm{i}}} \cdot \theta_{y_{\mathrm{i}}}: \mathrm{x}$ 軸廻り・y軸廻りの回 軾変位である。図一 6 中の $\mathrm{u} ・ \mathrm{v}$ は柱梁などの骨組要素 と結合するため必要な $\mathrm{x}$ 方向および $\mathrm{y}$ 方向の面内変位を 示している。 

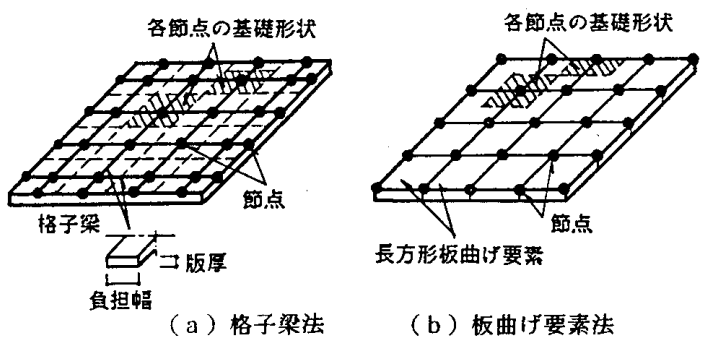

(b) 板曲げ要素法

図-4 底盤のモデル化の手法

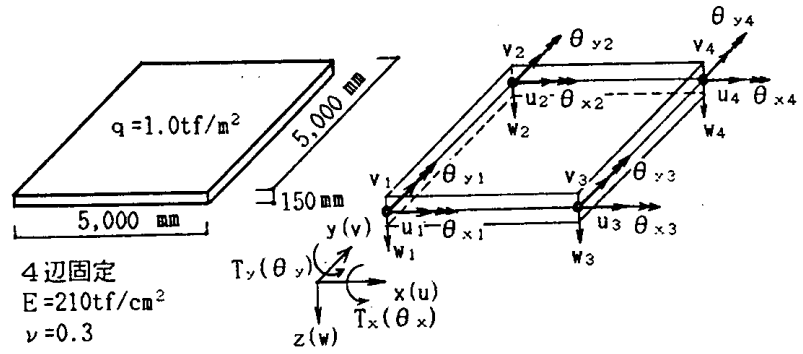

図-5 分割数検討用床版 図-6 長方形板曲げ要素

格子梁法および板曲げ要素法による分割数および分割 形状は、表一 1 の左方欄および下方に示すごとくであっ て、これらによる検討結果を同表に示した。厳密解 ${ }^{(4)}$ と 比較すると、ねじれ剛性を無視した格子梁では、分割数 を細かくしても板中心のたわみにかなりの誤差が生じて いる。ねじれ剛性を考慮した場合には板中心のたわみの 誤差は小さくなるが、板中心の曲げは20\%を超える誤差 が出ている。一方、板曲げ要素では 8分割以上であれば たわみ・曲げ応力とも $4 \%$ 以下の䛊差に収まっており、 格子梁よりもかなり精度がよいことがわかる。変6 分割 （中央部を粗に分割）は、節点数をできるだけ少なくす る意図で試みに行ったものであるが、板中央の曲げ応力 以外は非常に精度がよい結果が得られた。

(2)弾性地盤上の床版の沈下解析

図一 7 に示す有限厚さの弾性地盤上の矩形版に等分布 荷重が作用する場合を検討する。床版のモデル化は (1) の検討結果から板曲げ要素に限定し、分割数は変 6 分割 と10分割を設定する。地盤および床版の解析条件および 定数は図中に示したとおりである。床版の弾性係数 $\mathrm{E}=$ $210 \mathrm{tf} / \mathrm{cm}^{2}$ の場合の他、床版の剛性が 0 の場合（床版の $\mathrm{E}$ を0.001倍)と心の場合（床版の $\mathrm{E}$ を1000.0倍）の解析 結果をも比較して、図一8に示す。ただし床版の各辺に 平行な中心断面の值である。版の剛性が 0 の場合には、 沈下量・接地圧とも簃密解 ${ }^{15)}$ とほとんど一致している。 剛性がめの場合は厳密解がないので、変6分割と10分割 間で比較すると、版中央に近づくほど両者の接地圧に差 が生じる傾向がみられ、 $\mathrm{E}=210 \mathrm{tf} / \mathrm{cm}^{2}$ の場合は、この 差が小さくなっている。このように、変6 分割は版中央 部の精度に幾分問題が残るが、上部構造と下部構造の変 形を適合させるという大目的であること、設計上での奏
表-1 床版の分割数検討結果

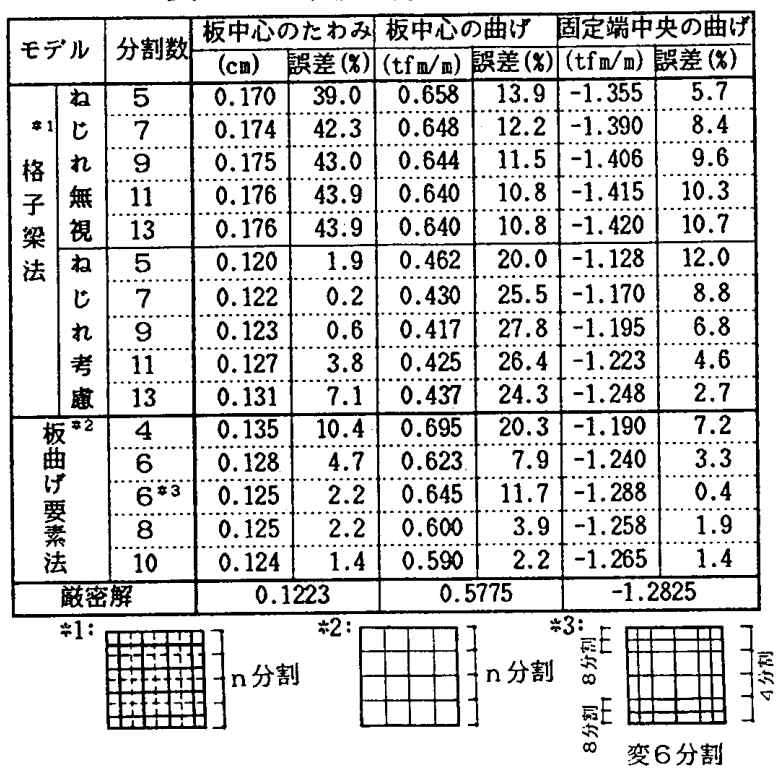

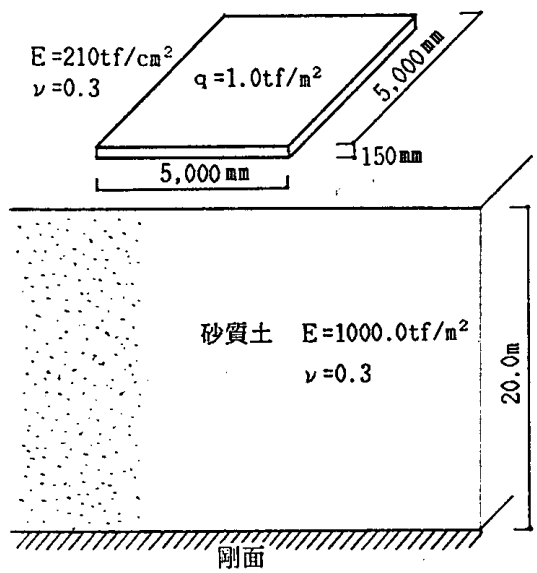

図一 7 弾性地盤上の床版

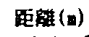

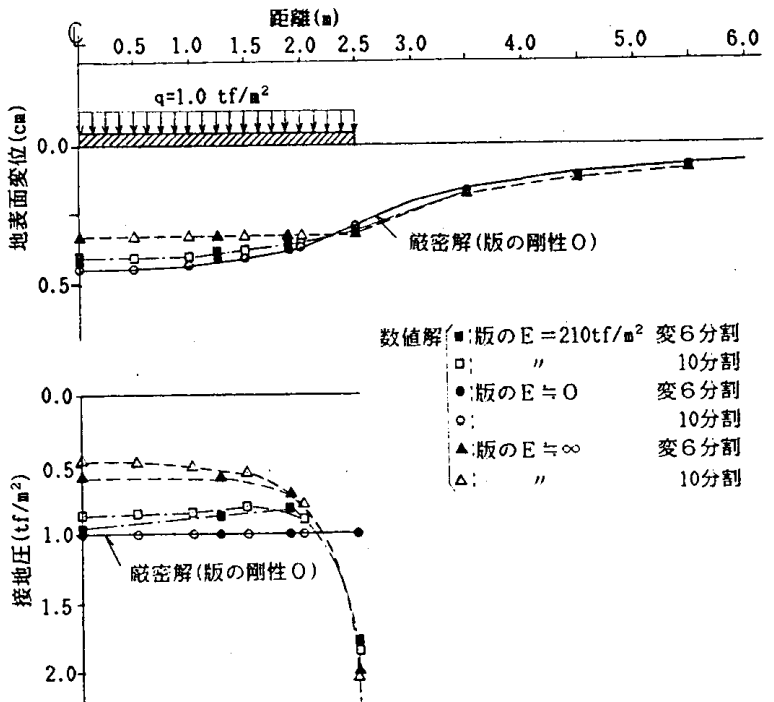

図-8 地盤上の床版の中心断面での沈下量・接地圧

用性を考えた場合、この程度の䛊差は許容されるものと 判断される。 
以上の検討結果より、本解析法ではべた基礎の底盤を 板曲げ要素としてモデル化し、分割形状は変6 分割を採 用することとする。

\section{3.べた基礎建物の不同沈下解析例}

\section{1 解析モデルと設定条件}

解析モデルは基本的に文献1) と同じであって、図 -9 に示す長辺 5 スパン、短辺 3 スパン、3 層の鉄筋コンク リート造のラーメン構造の建物である。地盤条件は、図 -10に示す地層が水平方向に一様な場合を想定する。砂 質土層は即時沈下のみ、粘性土層は飽和した正規圧密状 態とみなして、即時沈下は生ぜず圧密沈下のみが生じる ものとした。地盤の非線形性の考虑に必要な粘性土層の $\mathrm{e} \sim \log \mathrm{P}$ 関係、初期有効圧、砂質土層の $\mathrm{P} \mathrm{S}$ 検層によ る初期弾性係数 $\mathrm{E}_{\mathrm{pS}}$ の値などは、図一10中に示した。

べた基礎の底盤は、版厚 $20 \mathrm{~cm}$ とし、建物最下層に一様 厚さに打設されるものとした。比較のために採用する独 立基礎（記号 $\mathrm{F}_{1}$ ）は、フーチングの大きさをすべて 3.0 $\times 3.0 \mathrm{~m}$ 角（図一 9 および図一10の破線参照）とした。

上部構造の部材断面は、不同视下が生じない場合は、 通常の載荷重に対して十分許容応力度以内に収まる程度 に設定してあり、柱は各階ごと、梁は各階ごとおよび方 向別に同じ断面であるとして、表一2のように定めた。 なお、柱の $\mathrm{M}_{\mathrm{c}}$ および $\mathrm{M}_{\mathrm{y}}$ 計算用の軸力は建物内部柱 $(\mathrm{X} 3$ -Y2）に代表させて、各階ごとに同じと仮定した。建物荷 重は全体として $5 \mathrm{tf} / \mathrm{m}^{2}(\mathrm{R}$ 階: 0.8、3 階・2 階: 1.2 、 1 階 : $\left.1.8 \mathrm{tf} / \mathrm{m}^{2}\right)$ とし、各階柱位置にその負担面積を乗 じて集中荷重として作用させる。すなわち、通常の応力 解析 (基礎不動) による曲げモーメントは考えず、不同 沈下による曲げモーメントのみを考虑するものとする。

解析例としては、即時沈下および圧密沈下の別、基礎 形式の別、部材の塑性化およびクリープの考慮・非考慮 を想定し、表一 3 に示す 7 種類のCASEを設定した。ただ し、压密沈下に伴う地反力の変動の影響を直接的に受け るGL-4. 0m までの第 1 砂層の即時沈下はすべてのCASEで 考慮するものとする。また、上部構造の塑性化について は文献 ${ }^{(3)}$ に従って、略算的に部材の両端で得られる $a$ （図－3参照）の平均値を採用するが、べた基礎の底盤 は、応力状態にかかわらず弾性と仮定した。CASE-MMは、

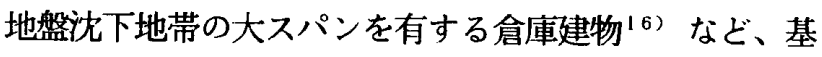
礎梁が設けられない場合の基䃈形式の一つとして考えら れる基礎底盤のみの基礎 $($ 版厚 $40 \mathrm{~cm}$ ）を想定したもので ある。なお、建物荷重の増分ステップ数は 10 とし、0.5 $\mathrm{tf} / \mathrm{m}^{2}$ づつを漸増させた。

\section{2 解析結果とその考察}

独立基礎の沈下量および反力の分布を図ー11に、べた 基礎の沈下量および接地圧の分布をCASE-1H, 2U, MII につ
いて図ー12〜図-14に、それぞれ示した。図ー15および 図一16には、Y2通りとX3通りラーメンの曲げモーメント 分布を、これらの通りの最外端スパンの変形角と梁の曲 げモーメントの関係を表ー4に示した。また、X1-Y1およ びX3-Y2基礎直下第 1 砂層（GL-0. 0m〜4.0m）の弾性係数

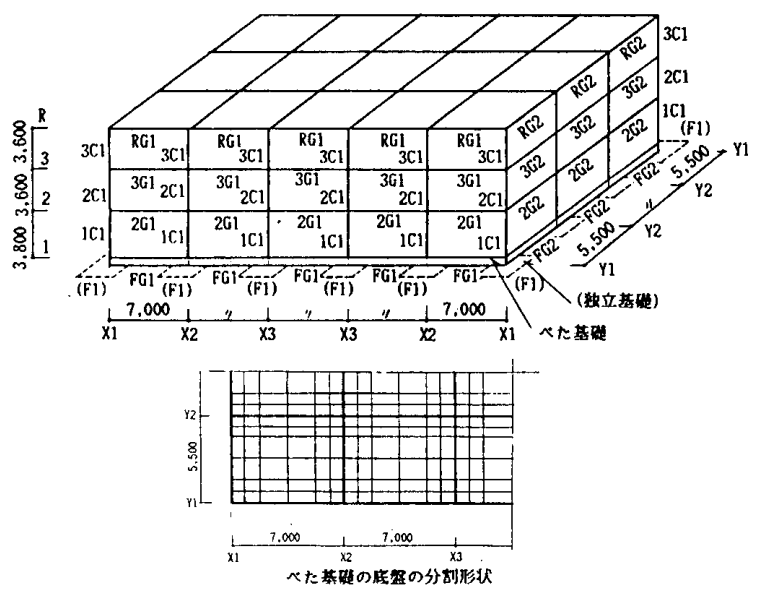

図-9＼cjkstart計算モデル

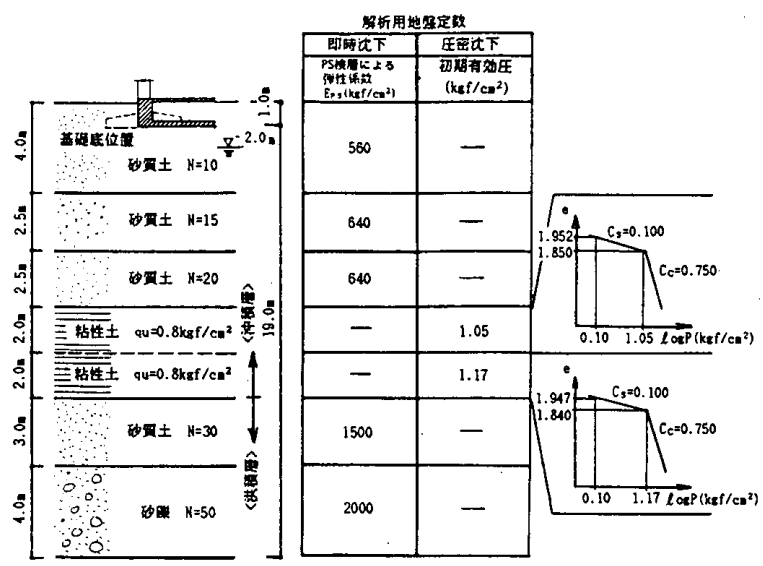

図-10 地盤条件

表 -2 計算モデルの部材の諸元

\begin{tabular}{|c|c|c|c|c|c|c|c|c|}
\hline \multirow[b]{2}{*}{ 符号 } & \multirow[b]{2}{*}{$D \times b(c m)$} & \multirow[b]{2}{*}{ 主解本数 } & \multirow{2}{*}{\begin{tabular}{|c|}
$\mathrm{K} \cdot$ \\
$\left(\times 10^{5} \mathrm{tfcm}\right)$ \\
\end{tabular}} & \multicolumn{3}{|c|}{ 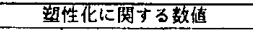 } & \multicolumn{2}{|c|}{ 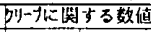 } \\
\hline & & & & $\begin{array}{l}\text { 嘈力 } \\
\text { (tf) }\end{array}$ & $\begin{array}{c}M_{e r,} M_{y} \\
(t f m)\end{array}$ & $\alpha_{x}, \alpha_{0}$ & $\beta$ & $\phi_{\mathrm{m} t}$ \\
\hline 301 & $60 \times 60$ & $\begin{array}{l}\text { (X) 3-D22 } \\
\text { (Y) 3-D22 }\end{array}$ & 3.78 & 30.8 & $\begin{array}{l}M_{c r}=12.4 \\
M_{y}=28.1\end{array}$ & $\begin{array}{l}\alpha_{y}=0.20 \\
\alpha_{0}=0.12\end{array}$ & 0.066 & 2.802 \\
\hline $2 \mathrm{Cl}$ & $60 \times 60$ & $\begin{array}{l}(\mathrm{X}) 4-\mathrm{D} 22 \\
(\mathrm{Y}) \text { 4-D22 }\end{array}$ & 3.78 & 77.0 & $\begin{array}{l}M_{c r}=17.0 \\
M_{y}=36.3\end{array}$ & $\begin{array}{l}\alpha_{y}=0.24 \\
\alpha_{0}=0.14\end{array}$ & 0.091 & 2.727 \\
\hline $1 \mathrm{Cl}$ & $60 \times 60$ & $\begin{array}{l}\text { (X) 5-D22 } \\
\text { (Y) 5-D222 }\end{array}$ & 3.58 & 123.2 & $\begin{array}{l}M_{c r}=21.4 \\
M_{y}=62.8\end{array}$ & $\begin{array}{l}\alpha_{\gamma}=0.28 \\
\alpha_{0}=0.20\end{array}$ & 0.093 & 2.721 \\
\hline RG1 & $70 \times 35$ & $\begin{array}{l}\text { (上) 3 D22 } \\
\text { (下) 3-D22 }\end{array}$ & 18.0 & 0.0 & $\begin{array}{l}M_{c r}=7.5 \\
M_{y}=23.8\end{array}$ & $\begin{array}{l}\alpha_{y}=0.31 \\
\alpha_{0}=0.24\end{array}$ & 0.100 & 2.700 \\
\hline 361 & $70 \times 35$ & $\begin{array}{l}(\text { L) } 4-1 \\
\text { (T) 4- }\end{array}$ & 18.0 & 0.0 & $\begin{array}{l}M_{c r}=7.5 \\
M_{y}=31.7\end{array}$ & $\begin{array}{l}\alpha_{y}=0.34 \\
\alpha_{0}=0.28\end{array}$ & 0.138 & 2.586 \\
\hline 201 & $75 \times 40$ & $\begin{array}{l}\text { (上) 4-D22 } \\
\text { (下) 4-D222 }\end{array}$ & 25.3 & 0.0 & $\begin{array}{l}M_{\text {cr }}=9.8 \\
M_{y}=34.1\end{array}$ & $\begin{array}{l}\alpha_{y}=0.31 \\
\alpha_{0}=0.24\end{array}$ & 0.114 & 2.685 \\
\hline RG2 & $70 \times 30$ & $\begin{array}{l}\text { (上) } 3-0 \\
\text { (T) } 3-0\end{array}$ & 19.6 & 0.0 & $\begin{array}{r}M_{c r}=6.4 \\
M_{y}=23.1\end{array}$ & $\begin{array}{l}\alpha_{y}=0.28 \\
\alpha_{0}=0.22\end{array}$ & 0.119 & 2.643 \\
\hline 362 & $70 \times 30$ & $\begin{array}{l}\text { (5) 4-D22 } \\
\text { (F) 4-D22 }\end{array}$ & 19.6 & 0.0 & $\begin{array}{l}M_{c r}=6.4 \\
M_{y}=31.7\end{array}$ & $\begin{array}{l}\alpha_{y}=0.32 \\
\alpha_{0}=0.27\end{array}$ & 0.116 & 2.652 \\
\hline $2 \mathrm{G} 2$ & $75 \times 35$ & $\begin{array}{l}\text { (上) 4-D22 } \\
\text { (下) 4-D22 }\end{array}$ & 28.2 & 0.0 & $\begin{array}{l}M_{e r}=8.6 \\
M_{y}=34.1\end{array}$ & $\begin{array}{l}\alpha_{y}=0.29 \\
\alpha_{0}=0.23\end{array}$ & 0.133 & 2.601 \\
\hline FG1 & $120 \times 40$ & $\begin{array}{l}\text { (上) 5-022 } \\
\text { (下) 5-D22 }\end{array}$ & 104.0 & 0.0 & $\begin{array}{l}M_{c r}=25.0 \\
M_{y}=70.1\end{array}$ & $\begin{array}{l}\alpha_{y}=0.22 \\
\alpha_{0}=0.15\end{array}$ & 0.092 & 2.724 \\
\hline $\mathrm{FG} 2$ & $120 \times 40$ & $\begin{array}{l}\text { (声) 5-D22 } \\
\text { (下) 5-D22 }\end{array}$ & 132.0 & 0.0 & $\begin{array}{l}M_{c r}=25.0 \\
M_{x}=70.1\end{array}$ & $\begin{array}{l}\alpha_{y}=0.19 \\
\alpha_{0}=0.13\end{array}$ & 0.092 & 2.724 \\
\hline$F 1$ & $\begin{array}{l}\ell x=300 \\
\ell y=300\end{array}$ & & & & & & & \\
\hline & $x_{\alpha}^{2}$ & & & & & & & \\
\hline
\end{tabular}


表一 3 解析ケースと考慮因子

\begin{tabular}{|c|c|c|c|c|c|c|c|c|}
\hline \multirow{2}{*}{ CASE名 } & \multirow{2}{*}{ 即時沈下 } & \multicolumn{3}{|c|}{ 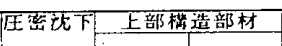 } & \multirow{2}{*}{ 地㤎の } & \multicolumn{3}{|c|}{ 基碓形式 } \\
\hline & & 正规压密 & 塑性化 & 3 נ & & 罣碳 & 莰碰 & 基磁梁無 \\
\hline CASE-1 & 0 & & 0 & & 0 & 0 & & \\
\hline CASE-2 & $\Delta$ & 0 & 0 & & 0 & 0 & & \\
\hline $\operatorname{CASE}-1 y$ & 0 & & 0 & & 0 & & 0 & \\
\hline CASE-2ME & $\stackrel{\Delta}{\Delta}$ & 0 & & & 0 & & 0 & \\
\hline CASE-2U & 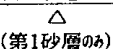 & 0 & 0 & & 0 & & 0 & \\
\hline CASE-2KC & (第1 $\Delta$ & 0 & 0 & 0 & 0 & & 0 & \\
\hline CASE- $\boldsymbol{\Psi}$ U & $\Delta \quad \Delta$ & 0 & 0 & & 0 & & & 0 \\
\hline
\end{tabular}

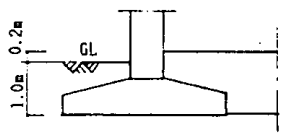

独立基硞

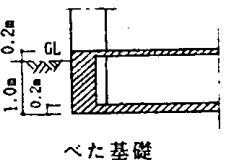

へた基路

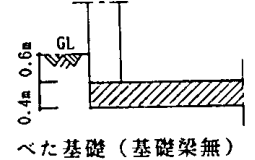

へた基碳（基碳梁無）
の推移を、CASE-1 とCASE-1Hについて図-17に、CASE-1M, 2H, MI のべた基礎の底盤の曲げモーメント分布を、基礎 梁位置と各スパンの中央部について図ー18に示した。こ れらの図表より、以下のことが指摘できる。

1）独立基礎のCASE-1およびCASE-2とも上部構造の剛性 により荷重が建物中央部から外端部に移行し、沈下量は 上部構造の剛性を考えない場合と比較すると、かなり均 等化されている（図一11参照）。ただし、上部構造には 大きな不同沈下応力が発生している（図一15参照）。と くに、CASE-1の即時视下でも、最大部材角が $2.44 \times 10^{-3}$ 、 基礎梁応力が51.2tfm（ $\mathrm{M}_{y}$ の約70\%）発生していて、無 視できない応力であることがわかる（表一4参照）。こ れは、3.0×3.0mの独立基礎を通して荷重が集中的に作 用し、上部砂質土層の弾性係数の低下割合に差が生じた たことも一因である（図-17参照)。CASE-2の沈下量は、 CASE-1の約 3〜6倍に達している（図-11参照）。しか し、表-4の変形角では1.5 1.9倍、曲げモーメントで は1.2 1.4倍に留まっている。圧密層の位置が深いこと によるものであって、変形角が必ずしも沈下量に比例し ないことを示している。

2）砂筫土の即時沈下を対象としたCASE-1、CASE-1Mを比 較すると（図ー11および図-12参照)、CASE-1Wではべた 基礎の剛性によって変形角が大幅に減少（表一4におい $\tau 、 2.44 \sim 2.33 \times 10^{-3} \rightarrow 0.47 \sim 0.27 \times 10^{-3} \mathrm{rad}$ ) し、上部 構造の曲げモーメントは 1 階端柱以外でほとんど発生し ていない（図一15参照）。沈下量の大きさもCASE-1より すべての点で小さな值となった。基礎梁の曲げモーメン 卜は、CASE-1Mでは地反力により凸形状となっているが、 その最大値は両者に顕著な差は出ていない(図-15参照)。 CASE-1H のこれらの現象は、べた基礎の大きな接地面積 によって荷重が緩やかに分散されることの他、上部秒質 土層の弾性係数の低下が建物中央部 (X3-Y2基礎)で非常 に小さく、建物端部（X1-Y1基礎)で大きくなる現象が生 じ沈下が均等化されたことによるものと考えられる（図

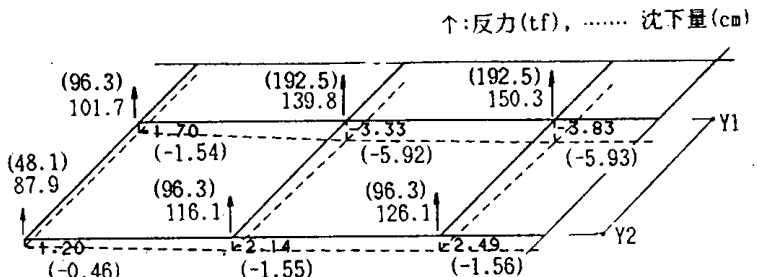

( a )C.ASE-1
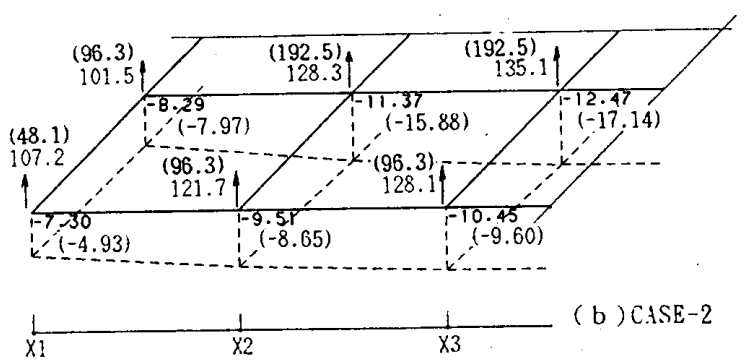

（）内数値は上部權造の剧性を無視した場合を示す

図-11 独立基礎の沈下量および反力の分布

表-4 外端部の変形角と曲げモーメント

\begin{tabular}{|c|c|c|c|c|c|c|}
\hline \multirow[b]{2}{*}{ 計算CASE } & \multicolumn{2}{|c|}{ 変形角 $\left(\times 10^{-3} \mathrm{rad}\right)$} & \multicolumn{4}{|c|}{ 典げモーメント(tfm) } \\
\hline & X3通n & Y2通 & 基娖 & 梁 & $\frac{2}{X 3, Y 1-Y}$ & $\frac{20}{2, x 1 \times \times 2}$ \\
\hline & & & & & & \\
\hline CASE-1 & 2.44 & 2.33 & 51.2 & 43.5 & 23.3 & 22.9 \\
\hline CASE-2 & 3.67 & 4.40 & 62.1 & 52.8 & 30.3 & 32.5 \\
\hline CASE-IY & 0.47 & 0.27 & 48.2 & 55.3 & 2.5 & 0.9 \\
\hline CASE-2KE & 1.45 & 1.76 & 104.6 & 98.3 & 32.3 & 32.8 \\
\hline CASE-2V & 2.42 & 2.67 & 78.5 & 83.0 & 24.3 & 23.7 \\
\hline CASE-2YC & 3.93 & 3.76 & 34.5 & 59.4 & 13.3 & 13.3 \\
\hline CASE-MY & 2.25 & 2.51 & & & 23.2 & 22.2 \\
\hline
\end{tabular}

-17参照）。ちなみに、X3-Y2基礎直下GL-2.5m地点（第 1砂層中)の最終ステップの E は、CASE-1で $75.0 \mathrm{kgf} / \mathrm{cm}^{2}$ 、 CASE-1Wで560. $0 \mathrm{kgf} / \mathrm{cm}^{2}$ であった。

3），粘性土の圧密沈下を対象とした CASE-2と、CASE-2M の沈下量の比較では、共に $10 \mathrm{~cm}$ 前後の数值を示すものの 後者の方がより平坦な分布形状となっていることがわか る（図一11および図－13参照）。表一 4 の変形角では、 後者は前者に対して約 0.6倍の大きさとなった。また、 上部構造の曲げモーメントも、CASE-2M はCASE-2の值以 下であって（図-15参照）、最も応力の大きい2階梁で も $\mathrm{M}_{y}$ の 70\%（表一4参照）程度に収まっている。ただ し、基礎梁には最外端スパンの内端でCASE-2の1.2〜1.5 倍の曲げモーメントとなり、曲げ降伏が発生している。 これらの結果は、べた基礎の剛性之荷重分散効果による ものであって、最外端スパシの基礎梁に大きな曲げ応力 が発生するものの、べた基礎は不同沈下軽減対策として の効果が大きいことがわかる。

4）図-12および図-13よりCASE-1山およびCASE-2Mのべ た基礎の接地圧は、全体的にみて上部構造の㓮性によっ て建物外周部に集中する傾向が認められる。図-8の接 地圧が端部に集中する現象と対応する。この現象は、即 時沈下 (CASE-1M) 上り沈下量の大きい圧密沈下 (CASE2W)において顕著であり、CASE-2Mの建物隅では建物平均 


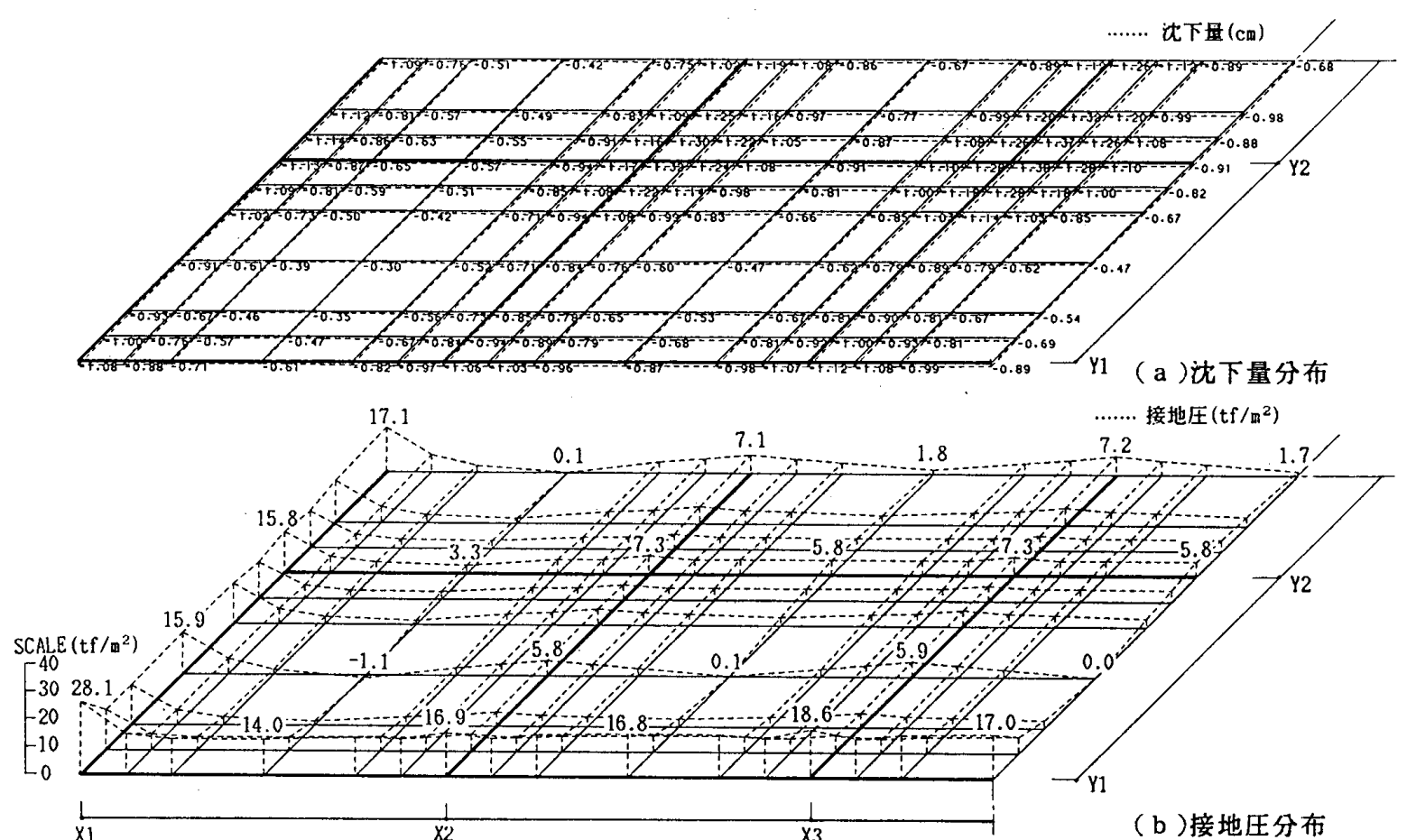

接地压 $\left(\mathrm{t} f / \mathrm{m}^{2}\right)$

図ー12 べた基礎（CASE-1M）の沈下量および接地圧の分布

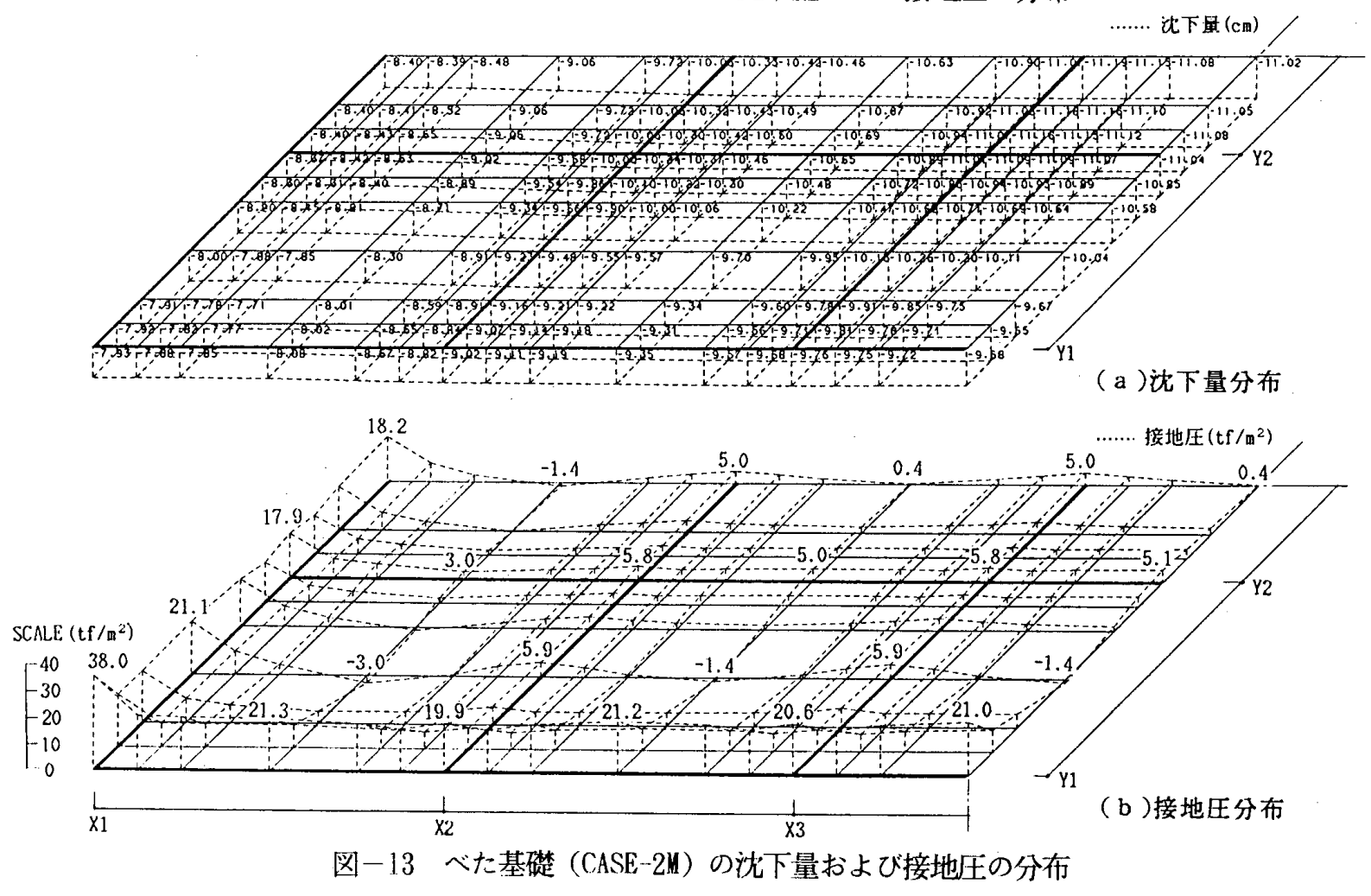

荷重 $\left(5.0 \mathrm{tf} / \mathrm{m}^{2}\right)$ の約 8 倍 $\left(38.0 \mathrm{tf} / \mathrm{m}^{2}\right)$ の值が発生して いる。通常、べた基礎の接地圧は基礎不動とした柱脚の 軸力をその負担面積で割った值としており、建物中央部 で大きく、建物端部では小さく設定されているが、この 仮定では問題があることが指摘できる。

5）同じく図-12および図－13において、各スパン中央 断面上での基礎底盤の接地圧分布は、基礎梁支点部で大
きく中央部で小さくなる形状を示し、中央部接地圧で負 となっている簓所もある。一般には、上部構造の床荷重 を各梁に分割する方法に準じて、図一19に示すように接 地圧の基礎梁への伝達を想定しているが、基礎梁中央部 については、過大評価の目担となり、基䃈梁端部では過 小評価となっている。

6） CASE-1M、CASE-2Mのべた基礎底盤の曲げモーメント 


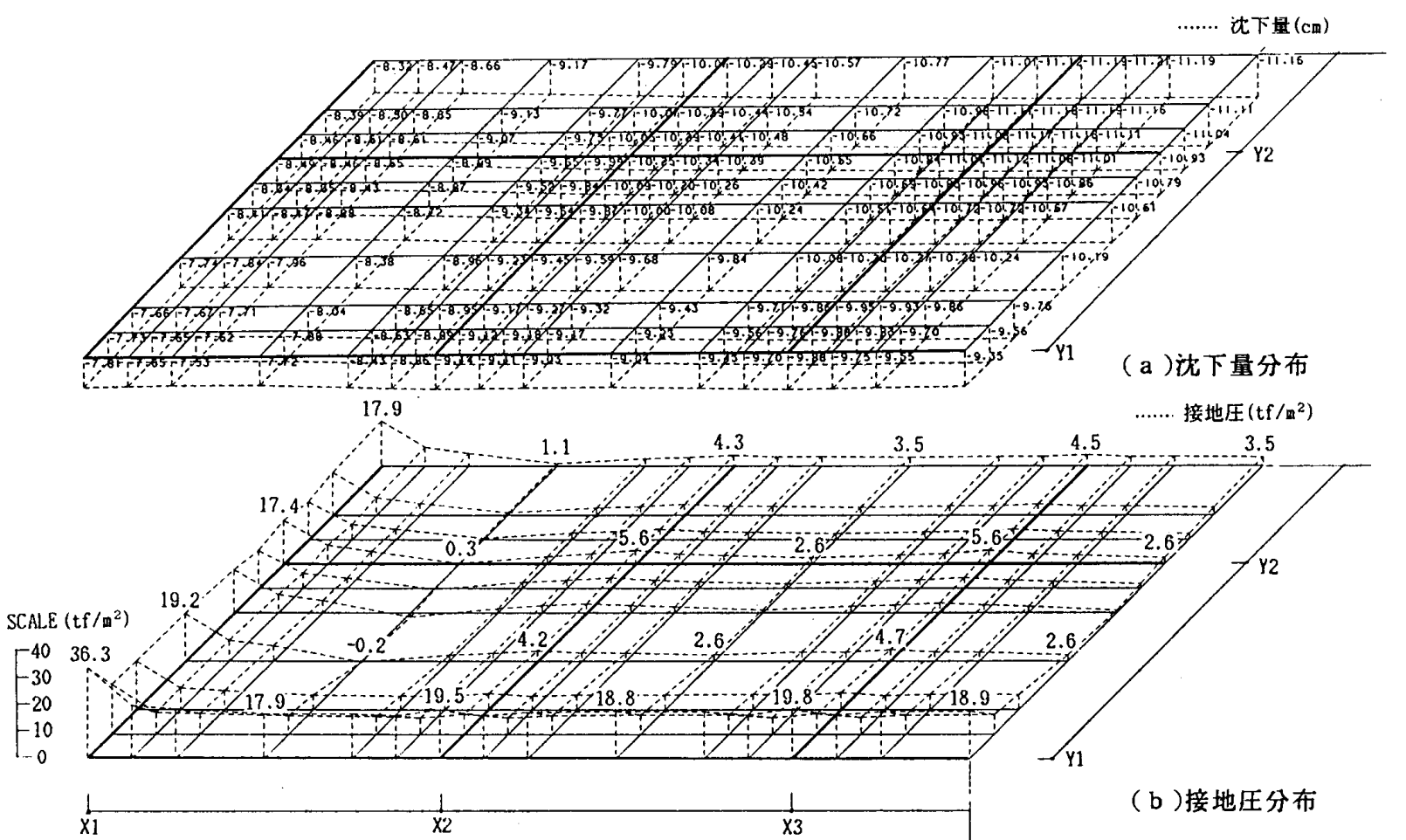

図-14 べた基礎（CASE-MM）の沈下量および接地圧の分布

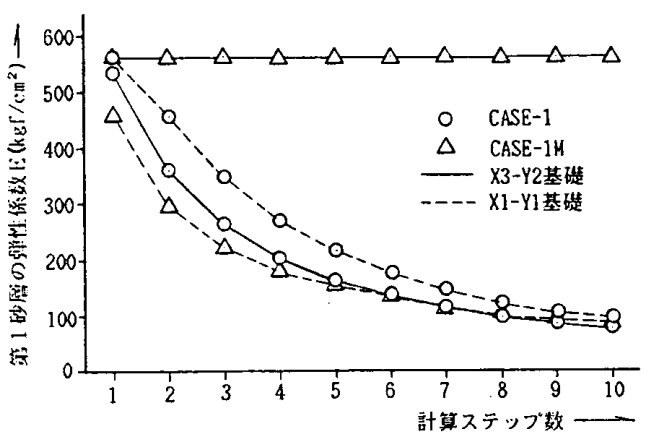

図-17 CASE-1, CASE-1Mの第 1 砂層 の弾性係数の推移

は、地反力を受けて版の端部で下側に、中央部 で上側に生じている（図-18参照）。建物外周 部により接地圧が集中したCASE-2Mは、CASE-1M に比べ全体的に曲げモーメントが小さくなって いる。これは、CASE-2Mの建物外周部を除く中 間部の地反力が CASE-1Hより小さいためであり （図一12および図-13参照）、底盤の曲げモー メントは地反力の大きさと分布形状に影響され ることが分かる。7. $0 \mathrm{~m} \times 5.5 \mathrm{~m} の 4$ 辺固定床版に $5.0 \mathrm{tf} / \mathrm{m}^{2}$ の地反力が作用した場合の床版の固定 端中央の設計用曲げモーメント ${ }^{17)}$ は $12.6 \mathrm{tfm} / \mathrm{m} 、$ 版中央

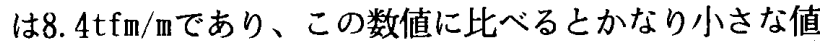
となった。現状の底盤の曲げモーメントの設定法は過大 評価であるといえよう。

7）基礎梁の無いべた基礎底盤だけを想定した CASE-MM の計算結果（図-14, 表-4参照）は沈下量の均等化の 程度および上部構造（2 階梁）の曲げモーメントともCA
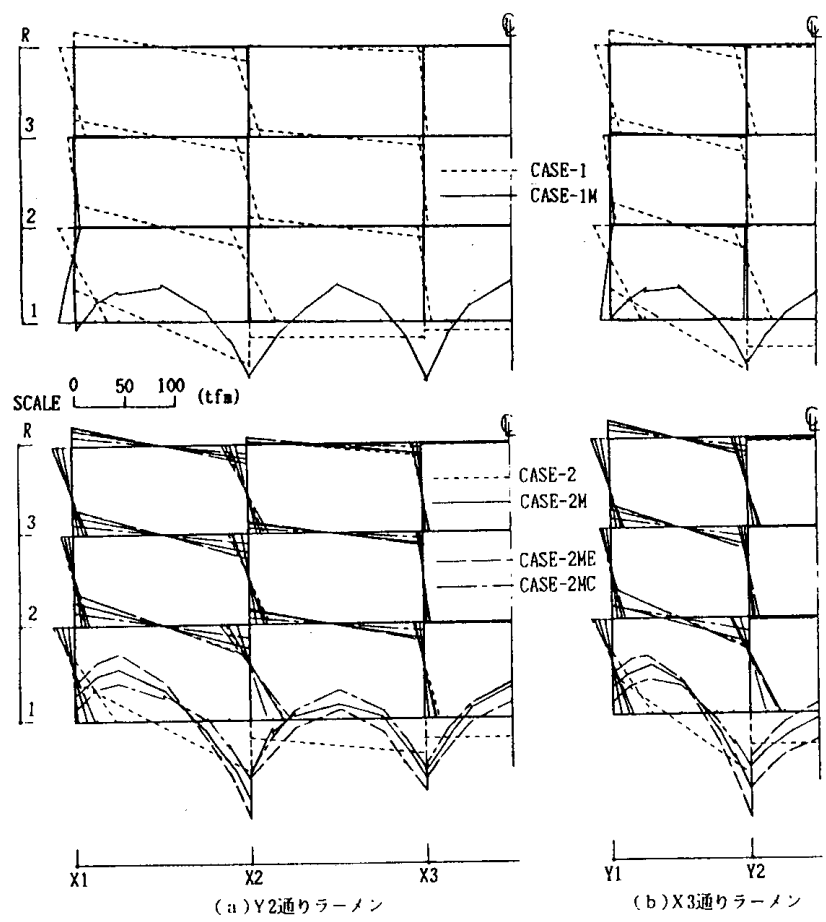

図-15 ラーメンの曲げモーメント分布

(CASE-1, 2, 1M, 2ME, 2M, 2NC)

SE-2H と大差なく、不同沈下軽減に関して同等の性能を 有していることが分かる。CASE-MMの底盤の曲げモーメ ント (図-18(C)参照)は柱脚位置で大きく生じており、 上部構造のフラットスラブ構造の応力状態を逆にしたよ うな分布形状となっている。底盤の曲げモーメントの最 大值は $\mathrm{X} 2-\mathrm{Y} 1$ 柱脚部分の $105.0 \mathrm{tfm} / \mathrm{m}$ であって、版厚 $40 \mathrm{~cm}$ であればかなり密な配筋が必要となる。したがって、フ 


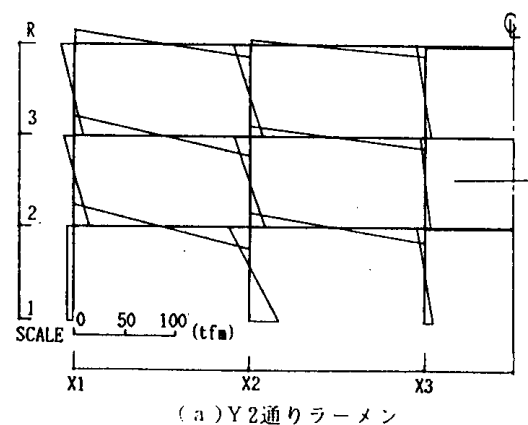

図一16 ラーメンの曲げモーメント分布 (CASE-MM)

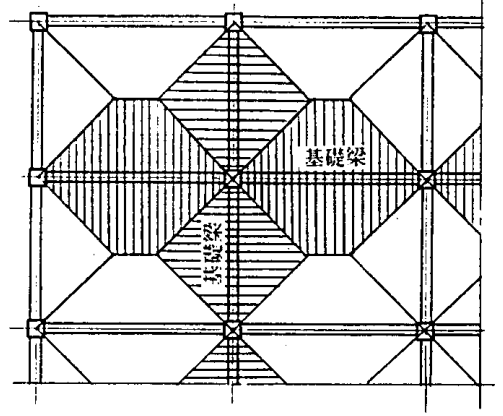

図一19 べた基礎の基礎梁の地反力の仮定

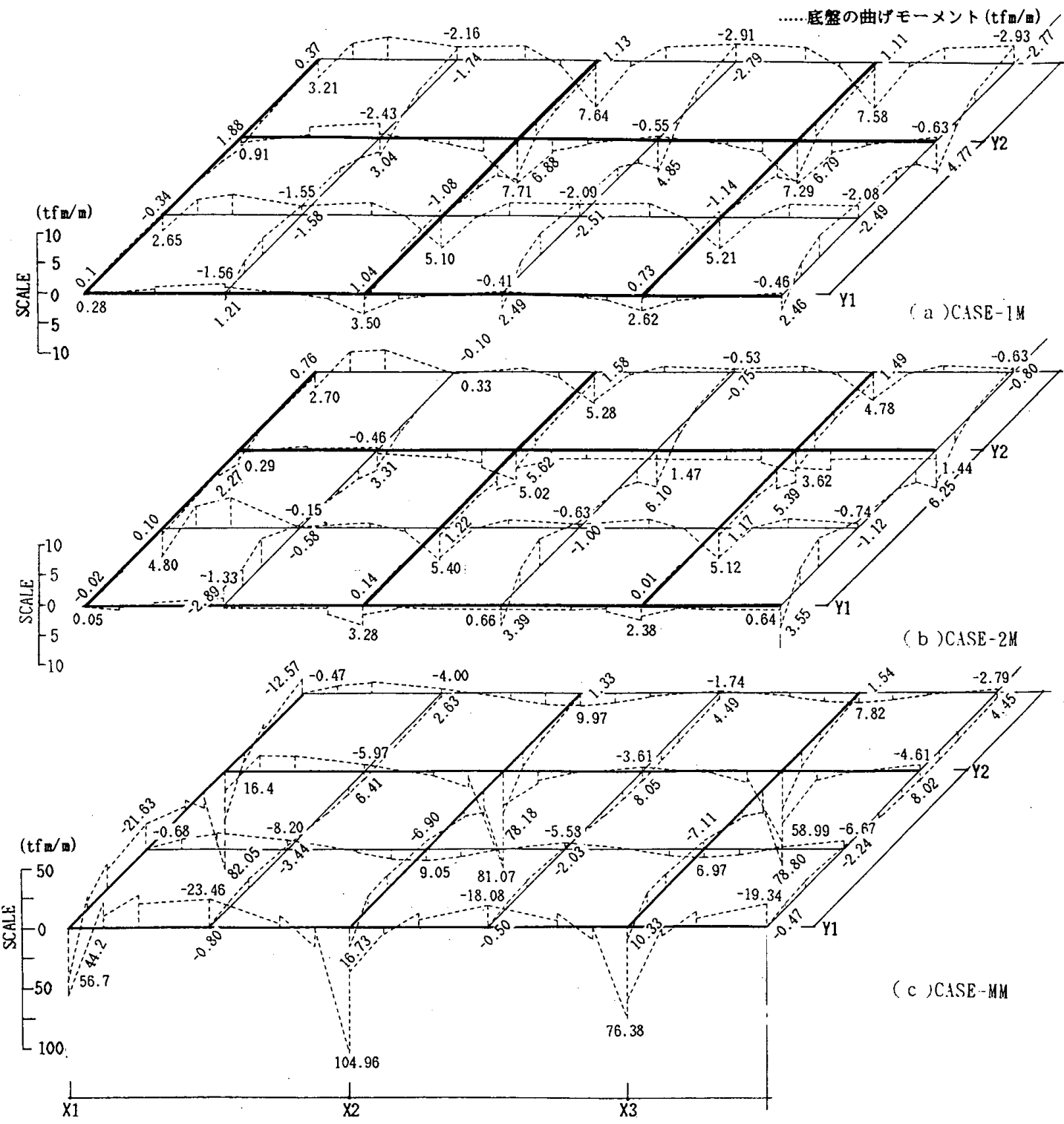

図-18 べた基礎底盤の曲げモーメント分布 (CASE-1H，2M，MM)

ラットスラブ構造と同様、柱脚部分にハンチや支圧板の 設置が必要であろう。しかしながら、このような基礎梁 のないべた基礎でも、かなりの不同沈下軽減効果が認め られ基礎形式の一つとして考えてよい之思われる。

8）上部構造の柱・梁を弾性としたCASE-2MEでは、最外
端スパンの基礎梁はすべて降伏モーメントを超えていて このような高応力が生じる場合には、部材を弾性として 算定することは現実的でない。塑性化およびクリープ変 形を考慮したCASE-2MCは、CASE-2M より㓮性が低下し、 最大部材角は $3.93 \times 10^{-3} \mathrm{rad}$ 、基礎梁の曲げモーメントは 
CASE-2Mに比べ約69〜72\%、CASE-2ME の約52 60\%の值 となった。長期間にわたり沈下が進行する圧密沈下にお いては上部構造部材の塑性化ならびにクリープ変形を考 慮すべきであるとして、上部構造が通常のラーメン体で ある場合への適用法はすでに文献 ${ }^{18), 19)}$ において述べら れているところである。べた基礎建物においても同様に 現実的な応力を求めるには、部材の塑性化やクリープの 影響を考慮する必要があろう。

\section{4.まとめ}

以上、べた基礎建物について、基礎底盤、基礎梁およ び上部構造の変形と地盤の変形を適合させ、地盤および 上部構造の非線形性を考慮した実用的な鉛直荷重時の応 力解析手法を提案した。基本的な解析手法は文献 ${ }^{1)}$ と同 様であって、上部構造の設計に多用されている3 次元骨 組解析プログラムに、地盤の変形を組み込むことによっ て構成したものである。底盤の力学的挙動は、長方形板 曲げ要素としてモデル化した。従来から、べた基礎の設 計は不同沈下を無視して柱軸力をその負担面積で割った 接地圧を下から作用させるといった慣用的な設計手法に よっていたが、本解法によって、べた基䃈建物の不同沈 下を考慮した合理的な設計手法が確立できたと考える。

次いで、本解法によって行った解析事例によって、以 下の事項を明らかにすることができた。

1）べた基䃈建物は、接地面積が大きいことによる荷重 分散効果之基礎底盤の剛性効果によって、独立基礎建物 と比べて、不同沈下が著しく軽減され、不同沈下対策と しての効果が大きいことがわかった。ただし、基礎梁の 最外端スパンには、大きな曲げモーメントが発生するの で、設計上の留意を要する。

2）べた基礎の接地圧分布は、全体として建物外周部に 集中する傾向があり、計算では建物平均荷重の8倍程度 の接地圧が算定された。現在慣用的に行われている柱軸 力をその負担面積で割って接地圧を求める方法は、建物 外周部の接地圧を過小評価することになり、注意が必要 である。

3）底盤の接地圧は、基礎梁支点部で大きく、中央で小 さくなる分布形状を示している。上部構造の床荷重と同 様な考え方による基硞梁の接地圧の設定方法では、基礎 梁中央部で過大評価であり、基礎梁端部では過小評価に なることが分かった。

4）基礎底盤の曲げモーメントは、接地圧の分布形状に 左右される。2)の建物外周部への接地圧の移行、3)の基 礎底盤中央部の接地圧の減少によって、底盤の曲げモー メントは、4辺固定床版に等分布の地反力が作用すると して計算した曲げモーメントよりかなり小さな数值とな った。現状のべた基䃈底盤の曲げモーメントの設定手法
は、過大評価であるといえる。

5）. 基礎梁を設けないべた基礎でも、その不同沈下軽減 効果は十分に発揮され、軟弱地盤地帯での大スパン構造 物の基䃈形式として有望であることが分かった。この場 合の底盤の曲げモーメントは、上部構造のフラットスラ ブ構造の応力状態の逆の分布形状となっていて、柱脚位 置の大きな曲げモーメントに対処するためには、ハンチ や支圧板の設置が必要となろう。

\section{参考文献}

1）松尾雅夫，山肩邦男：地盤の変形を考虑した鉛直荷重時立体 架構の実用解法, 日本建築学会構造系論文集, 第 455 号, pp. $83 \sim 92,1994.1$

2）山肩邦男, 过 英一, 北川 勝, 松尾雅夫, 小野俊博: 埋立 地盤におけるフローティング基礎の実施例，日本建築学会大 会学術講演梗概集, pp. 1059 1060，1985. 10

3）山肩邦男, 过 英一，松尾雅夫，小野俊博：埋立地船におり るフローティング基礎の挙動測定, 第26回土質工学研究発表 会講演集, pp. $1499 \sim 1502,1991.7$

4) R.F. Scott : Foundation Analysis, Prentice-Hall, pp. 173 197 (5.5 Mat or Raft Foundations : Baker's Method)， 1981

5）国田二郎：有限要素法による弾性地盤上の弾性平版の解析, 日本建築学会大会学術講演梗概集, pp. 913 914, 1979.9

6) G. Gagetas : Variational Estimation of the Settlem ent of a Circular Raft on Anisotropic Soil, Soils and Foundations, Vol.21, No.4, pp. 109 116, 1981.12

7）松井源吾, 佐藤勝利, 稲井栄一：べた基礎の応力分布の弾性 論的研究, 日本建築学会大会学術講演梗概集, pp. 581 582, 1985. 10

8）加藤史郎, 谷口伸一郎, 松岡 理 : 圧密層上にある弾性支持 タンクの応力解析, 日本建築学会大会学術講演梗概集, pp. 1015 1016, 1980.9

9）松浦 誠, 山本春行 : 軟弱地盤上のベ夕基礎を有する構造物 の不同视下に関する解析的研究，日本建築学会論文報告集， 第331号, pp18〜26, 1983.9

10）松尾雅夫, 山肩邦男 : 地盤の変形を考慮した鉊直荷重時ラー メン解法（べた基礎建物への適用法について），日本建築学 会大会学術講演梗概集, pp. 1605 1606, 1990. 10

11）松尾雅夫，山肩邦男 : 地盤の変形を考虑したべた基礎建物の 実用解法について, 日本建築学会大会学術講演梗概集, pp. $1831 \sim 1832,1993.9$

12）秋野矩之：地盤の剛性評価之建物の沈下予測一建築物の即時 沈下予測方法（その1），日本建築学会構造系論文報告集， 第412号, pp. 109 119, 1990.6

13）日本建築学会 : 鉄筋コンクリート構造計算規準・同解説, pp. $63 \sim 69,1991.4$

14）成岡昌夫, 丹羽義次, 山田善一, 白石成人：構造力学一第吕 巻板の力学, 丸善, pp. 174 181，1974.2

15) K. Terzaghi : Theoretical Soil Mechanics, J ohn Wiley \& Sons, pp. 423 425, 1943

16）井上 博：港湾埋立地のくいなし會庫，建築技術，№340, pp. $91 \sim 104,1979.12$

17）13)に同じ, pp. $77 \sim 78$

18）横尾義貫，山肩邦男，佐藤 寛：軟弱地盤における建築物の 不同沈下対策に関する基礎的考察, 日本建築学会論文報告集, 第65号, pp. $25 \sim 33,1960.6$

19）大崎順彦：建築基礎構造, 技報堂出版, pp. 350 367, 1991.1 